\title{
AYVALIDERE HAVZASINDA (SÜLEYMANPAŞA / TEKİRDAĞ) JEOMORFOLOJİK FAKTÖRLERIN TOPRAK ÖZELLİKLERİ ÜZERİNE ETKİLERİ
}

\author{
Emre ÖZŞAHIN*
}

\section{Özet}

Bu çalışmada, jeomorfolojik faktörlerin toprak özellikleri üzerine etkileri Ayvalıdere Havzası örneğinde incelenmiştir. Bu etkilerin örnek bir havza dâhilinde incelenmesi çalışmanın önemini teşkil etmektedir. Çalışmada 1:25.000 ölçekli KIRKLARELİ F19-d4 ve BANDIRMA G19-a1 numaralı topoğrafya haritaları kullanılmıştır. Yöntem olarak ise öncelikle havza alanının jeomorfolojik özellikleri tespit edilmiştir. Ardından başka araştırmacılar tarafından yaptırılan toprak örneklerinin analizlerinden ve çalışma bulgularından istifade edilerek havzanın detaylı toprak haritası oluşturulmuştur. Gerek jeomorfolojik özellikler (yer şekilleri, eğim, bakı, yükselti) gerekse toprak özellikleri CBS (Coğrafi Bilgi Sistemleri) ortamında karşılaştırılarak, havzada toprakların dağılışında jeomorfolojik faktörlerin etkisi irdelenmiştir. Çalışma sonunda yer şekilleri ile toprak özellikleri arasındaki ilişkinin kısa mesafeler dâhilinde büyük değişiklikler sunduğunu belirlenmiş ve vurgulanmıştır. Bu ilişkinin daha detaylı çalışmalarla ortaya konması gereklidir. Böylece elde edilen sonuçlarla toprak kaynaklarının korunması, doğru kullanımı ve planlanması konusunda önemli adımlar atılabilir. Nihai olarak gerek jeomorfolojik gerekse pedolojik özellikleri konu alan benzer çalışmalarda toprak ve yer şekilleri arasındaki münasebetin araştırılması doğal ortamı daha iyi anlayıp, analiz etmemize yardımcı olacaktır.

Anahtar Kelimeler: Toprak, Jeomorfoloji, Yer Şekilleri, Ayvalıdere Havzası, Tekirdağ.

* Namık Kemal Üniversitesi, Fen-Edebiyat Fakültesi, Coğrafya Bölümü, Öğretim Üyesi, Yrd.Doç.Dr. 


\title{
THE INFLUENCES OF GEOMORPHOLOGICAL FACTORS ON SOIL CHARACTERISTICS IN AYVALIDERE BASIN (SULEYMANPASA/TEKIRDAG)
}

\begin{abstract}
In this paper, the influences of geomorphological factors on the soil characteristics is studied on the basis of Ayvalidere Basin. The fact that these relationships are examined within a sample basin constitutes the significance of the study. In this study, KIRKLARELI F19-d4 and BANDIRMA G19-a1 topographic maps on a scale of 1:25.000 are used. As to methodology, firstly the geomorphological characteristics of the basin area were identified. Afterwards, the detailed soil map of the area was formed by making use of the sample soil analyses by other researchers and the other study findings. Whether or not geomorphological characteristics affect soil distribution in the basin was scrutinized by comparing and contrasting both geomorphological characteristics (landforms, slope, aspect, altitude) and soil characteristics on GIS (Geographic Information Systems). It was found and emphasized as a result that the relationship between landforms and the soil characteristics significantly differs even in short distances. There is a need for more detailed research on this relationship. Thus, the obtained results may be used to take concrete steps for the conservation of soil resource and their proper use and planning. Finally, similar research on the relationship between soil and the landforms dealing with pedological and geomorphological characteristics may help us to understand and analyze the natural environment better.
\end{abstract}

Keywords: Soil, Geomorphology, Landforms, Ayvalıdere Basin, Tekirdağ.

\section{Gíriş}

Ünlü Fransız jeomorfolog Jean Tricart (1920-2003), toprak özelliklerini normal jeomorfolojik araştırmaların bir tamamlayıcısı olarak jeomorfoloji konusuna dâhil etmek gerektiğini savunmuştur [1;2]. Gerçekten de toprak özellikleri ile jeomorfoloji arasında sıkı bir ilişki vardır [3; 4]. Zira dış etmen ve süreçler öncelikli olarak ana kayacın üst kısmında yer alan toprak tabakası üzerinde faaliyette bulunur. Bu faaliyet toprağın aşındırılması, parçalanması, taşınması ve bu parçaların daha sonra uygun bir alanda biriktirilmesi şeklinde gerçekleşir. Ayrıca bu durum jeomorfolojik oluşum ve gelişim sürecini de etkilemektedir [5].

Arazi kaynaklarının doğru ve sürdürülebilir kullanımını sağlamak amacıyla önem taşıyan [6; 7] toprak ve jeomorfoloji ilişkisine dayalı olarak yürütülen çalışmalar gün geçtikçe artmaktadır. Bilhassa toprakların haritalandırılması ve yer şekilleri ile olan ilişkilerinin açıklanması son birkaç on yılda popüler konulardan biri haline gelmiştir [8]. Driessen ve Meester (1969) Çumra Ovası'nda yaptıkları toprak araştırmasında toprak ordoları ile yer şekilleri arasında sıkı bir ilişkinin olduğunu belirtmişlerdir [9]. Malo vd. (1974) ile Ovales ve Collins (1986) yeryüzü şekillerinin karakteriyle toprakların genetik özellikleri ve profil gelişimleri arasında dikkate değer bir ilişkinin varlığını ortaya koymuşlardır [10; 11]. Özbek ve Güzel (1975) Seyhan Nehri boyunca oluşan taraçalar ile toprak özellikleri arasındaki ilişkiyi incelemişlerdir [12]. Briggs ve Shishira (1985) toprak etüt ve haritalama çalışmalarını yer şekilleri ve toprak özellikleri arasındaki 
ilişkinin varlığına dayalı bir şekilde gerçekleştirmeye çalışmışlardır [13]. Dinç vd. (1988) Harran Ovası'ndaki morfolojik birimlerin büyük toprak gruplarına uygunluk gösterdiğini tespit etmişlerdir [14]. Agbu vd. (1989) Nijerya'daki Skoto-Rima havzasındaki çeşitli jeomorfolojik birimler üzerinde oluşmuş toprakların, temel özellikleri arasındaki farklılıkları ispatlamışlardır [15]. Nizeyimana ve Bicki (1992) jeomorfolojik üniteler boyunca toprakların fiziksel, kimyasal ve mineralojik özellikleri arasındaki değişiklikleri incelemişlerdir [16]. Mutluer (1996) Orta Gediz Havzası'nda yer şekilleri ile toprak arasındaki ilişkinin tarım faaliyetleri üzerine olan etkisini incelemiş ve havzayı bazı agro-ekolojik kuşaklara veya yetişme ortamlarına ayırmıştır [17]. Kibar vd. (1998) Tuzla gölü baseni topraklarının fiziksel, kimyasal ve mineralojik özelliklerini yer şekilleriyle ilintili olarak detaylı bir şekilde etüt etmişlerdir [18]. Akgül ve Başyiğit (2005) 1.500 da yüz ölçüme sahip Süleyman Demirel Üniversitesi Çiftlik Arazisindeki alüvyal yelpaze ile alüvyal vadi tabanındaki toprak karakterini araştırmışlar ve çiftlik topraklarının önemli bir kısmının hafif eğimli bir alüvyal yelpaze üzerinde yer almakta olduğu sonucuna ulaşmışlardır [19]. Dengiz vd. (2006) Ankara ilinin yaklaşık 25 km güneyindeki Gölbaşı ilçesi ve yakın çevresinde bulunan farklı yer şekilleri üzerindeki toprakların fiziksel, kimyasal ve mineralojik özelliklerini saptamışlardır [20]. Dengiz ve Başkan (2010) Ankara Soğulca Havzası́ndaki toprak profil gelişimi ile yeryüzü şekilleri arasındaki münasebeti belirlemeye çalışmışlardır [21]. Özşahin (2013) Gönen Çayı Deltası'ndaki alüvyal toprakların fiziksel ve kimyasal özelliklerini tespit edip, sınıflandırmış ve deltanın jeomorfolojik faktörlerin toprak özellikleri üzerinde baskın bir etkisinin olduğunun altını çizmiştir [8]. Özşahin ve Atasoy (2015) Aşağı Asi Nehri Havzası̉ndaki toprak özellikleri üzerinde jeomorfolojik faktörlerin etkili olduğunu kayıt etmişlerdir [22]. Özşahin (2015) Tekirdağ şehri ve yakın çevresinde toprak oluşumunu etkileyen faktörlerden birinin de jeomorfolojik özellikler olduğunu ileri sürmüştür [23].

Bu çalışmada jeomorfolojik faktörlerin bilhassa da yer şekilleri ile toprak tipleri arasındaki ilişkinin, Ayvalıdere Havzası örneğinde incelenmesi amaçlanmıştır. Çalışma amacı çerçevesinde; "Ayvalıdere Havzasinın toprak özellikleri nasıldır? Bu havzada hangi toprak ordoları mevcuttur? Bunların dağılışı nasıldır? Havzada yer alan jeomorfolojik birimler hangileridir? Bunların toprak oluşumu ve özelliklerine olan etkileri nelerdir?” şeklindeki araştırma sorularına yanıtlar aranmıştır. Çalışma, jeomorfolojik özellikler bilhassa yer şekilleri ve toprak arasındaki ilişkinin örnek bir havza kapsamında incelenmesinden dolayı önem teşkil etmektedir. Ayrıca daha çok planlamalar için önem taşıyan bu yayından elde edilen bulgular ve sonuçlar, konu hakkında kuramsal çalışmalara ve hipotezlerin geliştirilmesine yardımcı olabileceği gibi, bu konuda çalışacak bilim insanlarına da bir kaynak teşkil edebilir.

\section{HAVZA ALANININ KONUMU VE BAŞLICA COĞRAFi ÖZELLIKLERi}

Ayvalıdere havzası, Türkiye’nin kuzeybatı kesimindeki Marmara Bölgesi’nin Ergene Bölümü’nde yer almakta olup, idari olarak Tekirdağ ilinin merkez ilçesi (Süleymanpaşa) sınırları 


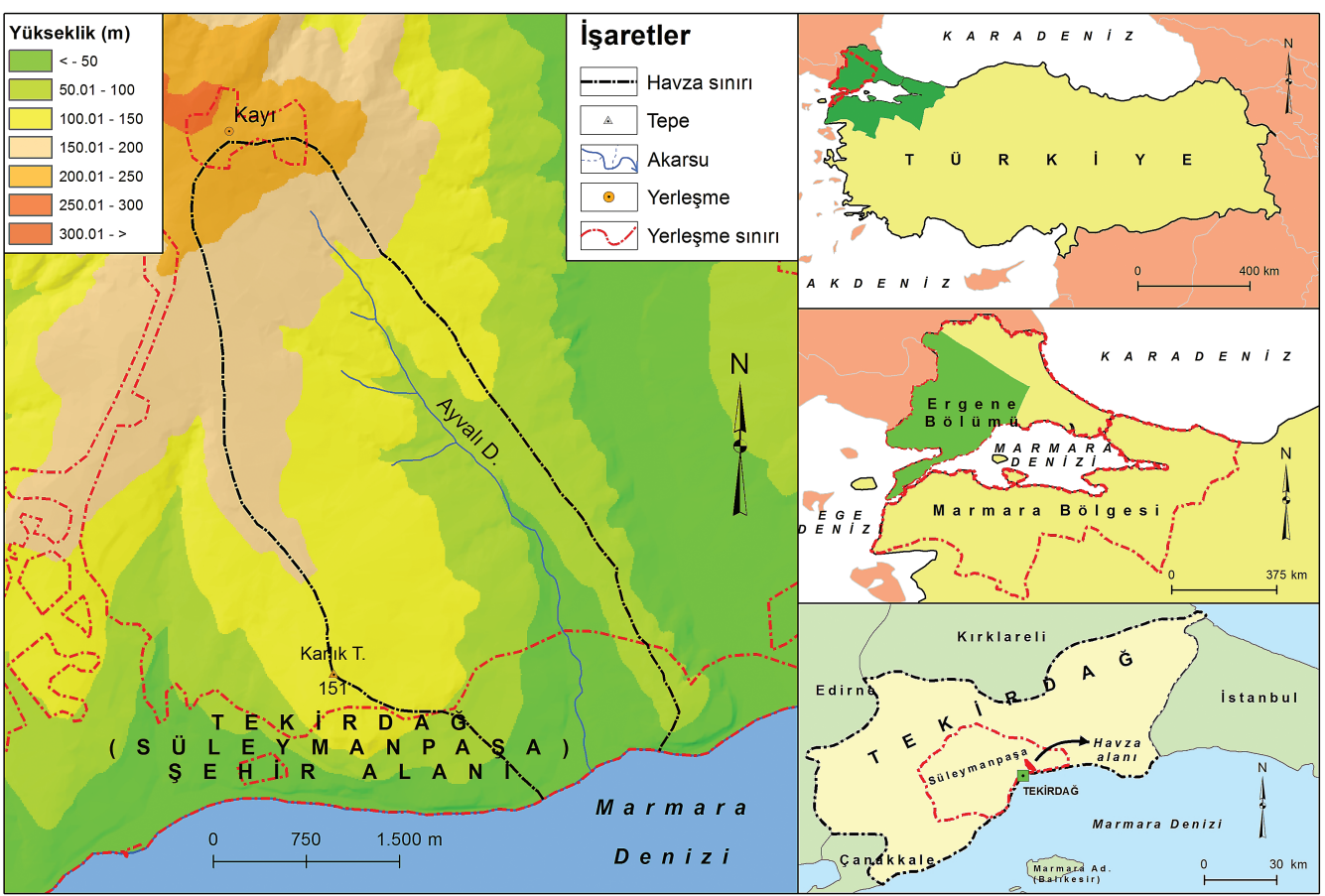

Şekil 1. Havza Alanının Lokasyon Haritası

dâhilinde kalmaktadır (Şekil 1). Ayvalıdere’nin su bölümü hatları ile sınırlandırılmış olan havzanın yüzölçümü ise $10 \mathrm{~km}^{2}$ 'dir (Şekil 1).

Ayvalıdere Havzası, sularını kısa bir mesafede Marmara Denizi’ne ulaştıran, KB - GD uzanımlı bir akarsu havzasıdır. Bu küçük havzada, akarsuyun kaynağı ile denize döküldügü yer arasında 5 km mesafe bulunmaktadır. Havzanın en yüksek noktası güneybatıdaki Karlık Tepe (151 $\mathrm{m}$ ), en alçak noktası ise deniz seviyesidir. Bu duruma göre havzadaki yükselti farkı 151 m’dir.

Trakya Havzası’nın güneyinde yer alan bu alanda, jeolojik olarak üç farklı formasyon yayılış göstermektedir (Şekil 2). Bunlardan en yaşlısı Orta-Üst Oligosen’e ait kiltaşı, kumtaşı ve siltaşı litolojilerinden meydana gelen Danişmen Formasyonu; en genci ise Kuvaterner'e ait alüvyonlardır (Şekil 2). Diğer formasyon ise çamurtaşı ve miltaşı litolojisindeki Orta-Üst Miyosen’e ait Ergene Formasyonu'dur [24]. Havza alanı tektonik olarak, Kuzey Anadolu Fay Zonunun batı uzantısında bulunan Ganos Fayı'nın kuzeyinde yer almaktadır [25].

Havza alanında jeomorfolojik olarak çeşitli irtifa seviyelerinde gelişim göstermiş plato ve denizel taraçalar ile yamaçlar, geniş tabanlı vadi ve delta bulunur [26]. Ayvalıdere ise Marmara Denizi Havzası'nda yer alan ve bu denize dökülen önemli akarsulardan birisidir.

Çevre ve Orman Bakanlığı Devlet Meteoroloji İşleri Genel Müdürlüğüne bağlı Tekirdağ Meteoroloji İstasyonu tarafından yapılan ve 1954-2013 yılları arasını kapsayan ölçüm sonuçlarına 


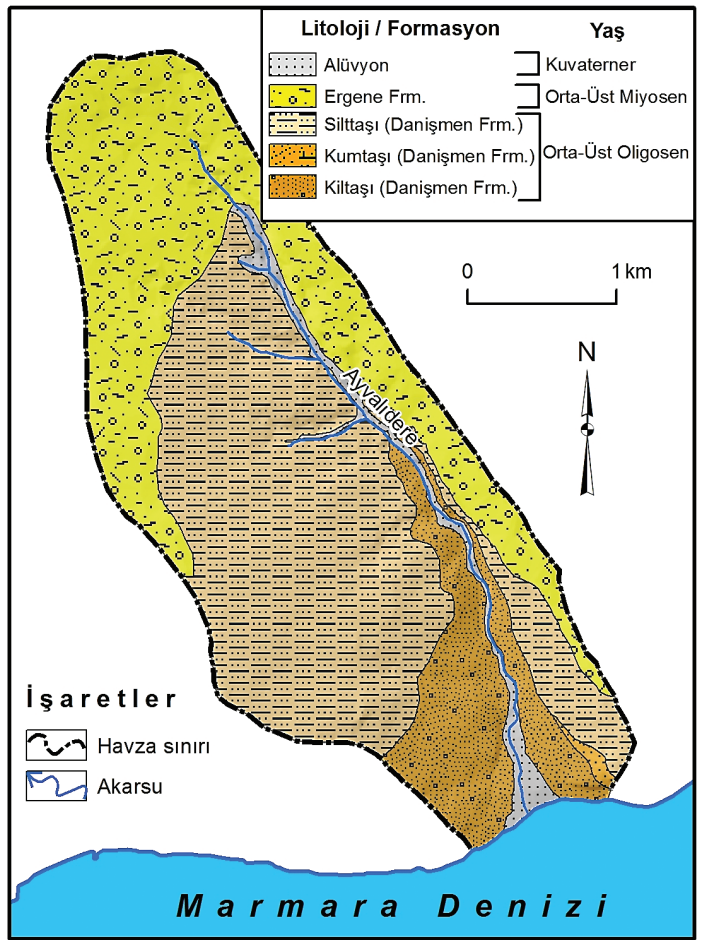

Şekil 2. Havza Alanının Jeoloji Haritası

göre havza alanında yıllık ortalama sıcaklık $14.1{ }^{\circ} \mathrm{C}$, yıllık toplam yağış ise 588.4 mm'dir [27]. Buna göre Akdeniz iklimi etki alanında yer almasına rağmen yaz kuraklığının Akdeniz iklimindeki kadar hissedilmediği bu sahada, Yarı Nemli Marmara (Geçiş) iklimi egemendir [28]. Ayrıca Thornthwaite metodu kapsamında yapılan değerlendirmeye göre havza alanı, C1 B’2 w b’3 sembolleriyle gösterilen, kurak yarı nemli - ikinci dereceden mezotermal - kış mevsiminde orta derecede su fazlası olan iklim sınıfı içerisinde bulunur [29].

Yakın çevrede yapılan toprak çalışmalarından elde edilen bilgiler ışığında havza alanındaki toprak nem rejimi xeric, sıcaklık rejimi ise thermic'tir [30]. Bu nem ve sıcaklık rejimi altında havza alanında çeşitli toprak ordoları gelişim göstermiştir [31; 32, 33, 34].

Havza alanında arazinin geneli Tekirdağ şehir merkezine ait mahalleler (Gündoğdu ve Hürriyet) ile Kayı mahallesi (Süleymanpaşa) tarafından yerleşim amaçlı olarak kullanılmaktadır. Bunun dışında tarım ve mera amaçlı kullanımlar da mevcuttur. Havza alanının bir kısmı, Tekirdağ çevre yolunun İstanbul istikametine, Bağlar mevkii sırtları ve Muratlı çevre yolu kavşağı arasında kalan arazilere tekabül etmektedir. Bu arazide çeşitli araştırmacılar tarafından toprak özelliklerinin saptanmasına yönelik çalışmalar gerçekleştirilmiş ve sonuçta sahadaki toprakların tarımsal üretim dışındaki kullanımlarına son derece dikkat edilmesi gerektiği vurgulanmıştır [31; 32, 33, 34]. Ancak ilgili yayınlarda sahanın herhangi bir toprak haritasına yer 
verilmemiştir. Bu çalışma havza alanının toprak haritasının oluşturulması temelinde kurgulanmıştır. Ancak toprak özelliklerinin dağılışı ile yer şekilleri arasında çok kuvvetli bir ilişkinin var olduğu anlaşılınca çalışmanın çerçevesi bu yöne doğru genişletilmiştir. Zira daha öncede Trakya Yarımadası'nda mikroröliyefin toprak oluşumundaki rolünün gayet açık bir şekilde olduğu ve çok küçük alanlar içinde dahi yer şekilleri üzerindeki toprak örtüsünün gözle görülür farklar taşıdığı bildirilmiştir [35].

\section{MATERYAL VE METOT}

Bu çalışmada temel materyal olarak 1:25.000 ölçekli KIRKLARELİ F19-d4 ve BANDIRMA G19-a1 numaralı topoğrafya haritaları kullanılmıştır. Yöntem olarak ise şu aşamalar takip edilmiştir. Öncelikle ilgili literatür eşliğinde tematik haritaların detaylı bir şekilde incelenmesi yapılmıştır. Bu aşama, çeşitli topoğrafik analizlerle (eğim, bakı, yükseklik) destekli olarak gerçekleştirilen arazi çalışmalarıyla da desteklenmiştir. Ardından toplanan veriler ışığında, havza alanının jeomorfolojik özellikleri bilhassa da yer şekilleri tespit edilmiş ve haritalanmıştır. Daha sonra farklı araştırmacılar $[31 ; 32,33,34]$ tarafından yapılmış toprak analizlerinden ve çalışma bulgularından istifade edilerek havzanın detaylı bir toprak haritası oluşturulmuştur. Gerek jeomorfolojik özelliklere ait tematik haritalar gerekse toprak haritası, CBS (Coğrafi Bilgi Sistemleri) ortamında karşılaştırılarak, havzadaki toprak özelliklerinin dağılışında jeomorfolojik faktörlerin etkisi irdelenmiştir. Çalışmadaki verilerin dağılışı ve haritalandırılması, ArcInfo/ ArcMap 10.3 paket programı kullanılarak gerçekleştirilmiştir. Nihai aşamada ise elde edilen veriler tekrar araziye çıkılarak yerinde kontrol edilmiştir.

\section{BULGULAR VE TARTIŞMA}

Jeomorfoloji ve toprak özellikleri arasındaki münasebeti konu alan bu çalışmada örnek uygulama alanı olarak Ayvalıdere Havzası seçilmiştir (Foto 1). Bu seçimde, havzanın küçük olmasına rağmen çeşitli yer şekillerini ve toprak ordolarını barındırması ile detaylı bir toprak etüdünün yapılmış olması etkili olmuştur. Zira bilimsel araştırmalardan elde edilen bulgulara göre küçük alanlardaki toprakların çalışılması sırasında topoğrafya veya röliyefin, ana materyalin ve zamanın toprak üzerindeki etkileri belirgin olarak görülmektedir [36; 37]. Ayrıca yakınlık ve veri temini de havzanın seçimindeki diğer bir gerekçe olarak gösterilebilir.

Ayvalıdere Havzası'nda, ana yer şekli olarak plato, elemanter yer şekilleri olarak da yamaç, denizel taraça, geniş tabanlı vadi ve delta bulunur (Şekil 3). Havza alanında, batı ve kuzeybatıda daha geniş, doğuda ise daha dar bir şekilde yayılış gösteren plato sathı, bölgede Pliyosen döneminde oluşmuş aşınım yüzeyinin sonradan Ayvalıdere ve sahadaki diğer akarsular tarafından derince yarılması neticesinde plato karakteri kazanmıştır. Post-Pliyosen tektonik hareketleri ile kısmen deforme olmuş olan bu aşınım yüzeyleriyle yaşıt depolar ise havza alanının çevresinde yayılış gösteren Trakya Formasyonuna ait akarsu çökellerini oluşturmuştur [26]. 


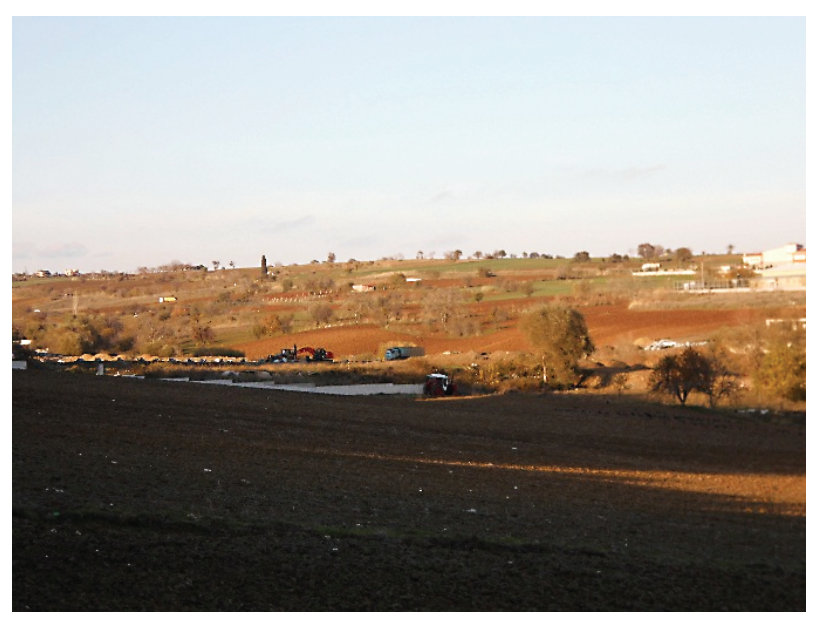

Foto 1. Havza Alanından Genel Bir Görünüm (Kuzeye Bakış)

Marmara Denizi’ne doğru eğimli olan bu plato yüzeyinin üzeri oldukça düz olup, eğim değerleri \% 2-5’ler arasındadır. Havza alanında 100 m’den itibaren gözlenen bu yüzeyler, Orta-Üst Oligosen silttaşı (Danişmen Formasyonu) ile Orta-Üst Miyosen siltli killeri (Ergene Formasyonu) üzerinde yayılış göstermektedir. Günümüzde bu plato sathının büyük bir kısmı Tekirdağ şehrinin mahalleleri (Gündoğdu ve Hürriyet) ile Kayı yerleşmeleri tarafından yerleşim amaçlı olarak kullanılmaktadır. Bunun dışındaki sahalardan ise tarım ve mera alanı olarak faydalanılmaktadır.

Havza alanındaki elemanter yer şekillerinden ilki yamaçlardır (Şekil 3). Eğim değerlerinin \% 10'nun üzerinde olduğu bu araziler, plato ve denizel taraçalar ile alüvyal vadi tabanı ve delta arasında geçişi sağlamaktadır. Havza alanındaki plato ile benzer litolojilerin tavanında yayılış gösteren bu birimler üzerinde bazı alanlarda fosil heyelanlar bulunmaktadır. Ayrıca bu arazilerin Marmara Denizi’ne doğru olan kesimlerinde falezli yüksek kıyılar hâkimdir (Şekil 3).

Havza alanında 50-55 m ve 80-85 m yükselti basamaklarında denizel taraçalar bulunur (Şekil 3). Bu taraçalar Marmara Denizi’nde meydana gelen seviye değişimlerinin etkisiyle ortaya çıkmışlardır. Ayrıca bu süreçte Kuzey Anadolu Fayı’nın da büyük etkisi olmuştur. Bu nedenle havza alanındaki denizel taraçalar Marmara Denizi’ne doğru eğimlenmişler ve akarsular tarafından yarılarak parçalı bir görünüm kazanmışlardır. Bu yer şekilleri üzerinde eğim değerleri $\%$ 2-5’ler civarındadır.

Havza alanındaki diğer bir yer şekli ise geniş tabanlı vadidir (Şekil 3). Bu yer şekli, ana akarsu yatağında kıyıdan 4 km içeriye kadar sokulmuş bir şekilde yayılış göstermektedir. Kuvaterner'e ait alüvyal dolgulardan (alüvyal vadi tabanı) oluşan bu arazide, eğim değerleri \% 2-3’ler arasındadır. Havza alanında geniş tabanlı vadinin denize ulaştığı kesimde tipik görüntüsünden uzak olmasına rağmen küt şekilli küçük bir delta gelişmiştir (Şekil 3). Yüzölçümü yaklaşık 12 ha 


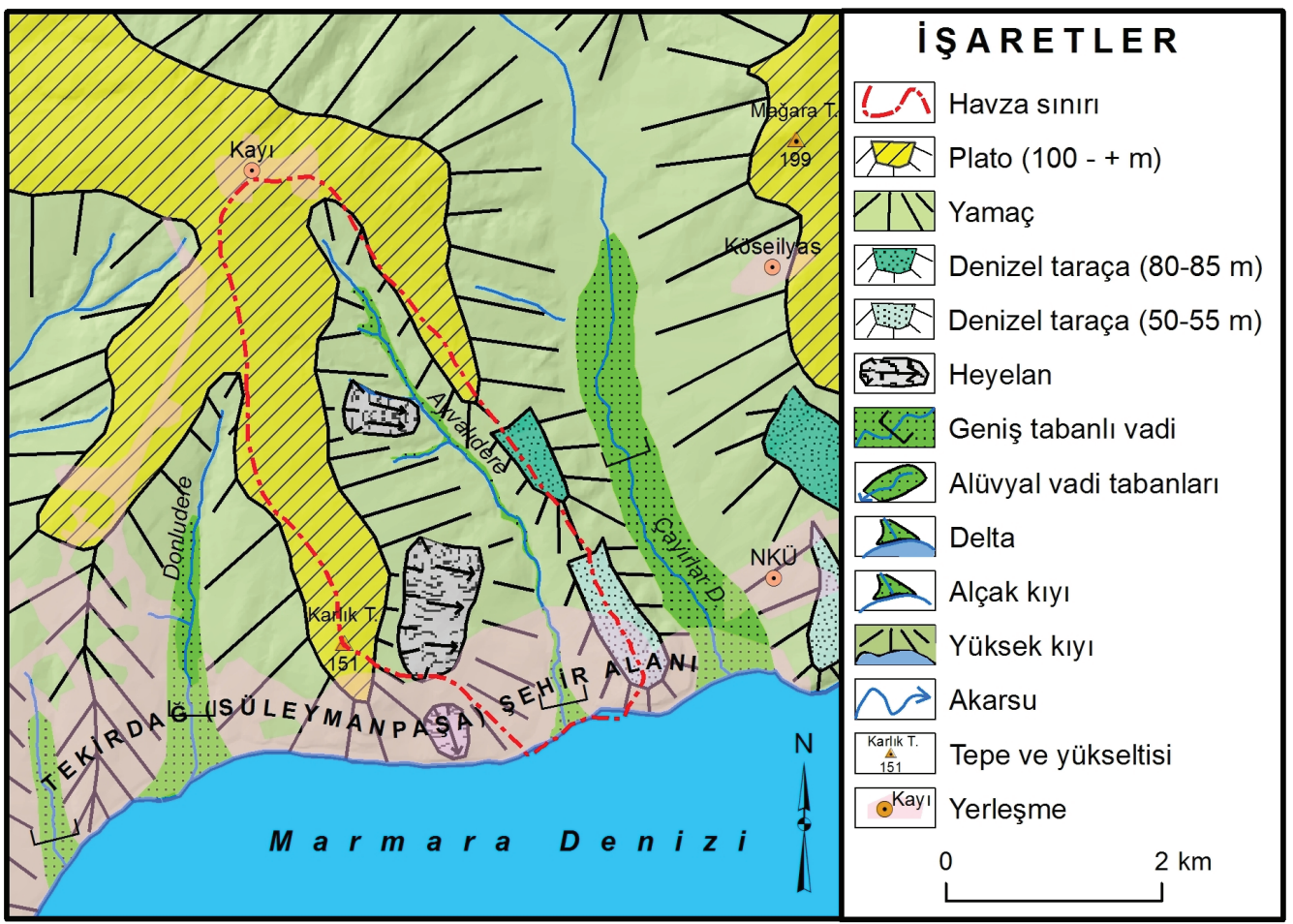

Şekil 3. Havza Alanı ve Yakın Çevresinin Jeomorfoloji Haritası

civarında olan bu yer şekli üzerinde ise eğim değerleri oldukça düşüktür. Havza alanı ve yakın çevresinde delta oluşumlarının görüldüğ̈̈ kıyılar, alçak kıyı karakterindedir (Şekil 3).

Havza alanının jeomorfolojik özellikleri (bilhassa yer şekilleri) toprak özelliklerine sirayet etmiş ve küçük bir alan dâhilinde çeşitli toprak ordoları yayılış göstermiştir (Şekil 4). Buna göre yapılmış toprak analizleri dikkate alınarak gerçekleştirilen sınıflandırma çerçevesinde havza alanında Entisol, İnceptisol (Foto 2) ve Vertisol olmak üzere üç toprak ordosu yer almaktadır (Tablo 1; Şekil 4). Bu toprak ordoları da kendi içerisinde üç alt ordo’ya, dört büyük gruba ve beş alt gruba ayrılmıştır [31; 32; 33; 34]. Havza alanında tanımlanan bütün bu farklı toprak sınıfları ile yer şekilleri, eğim, bakı ve yükselti özellikleri arasında belirli bir ilişki mevcuttur. Zira yapılmış araştırmalarda da ilgili münasebetten sık sık bahsedilmiştir [21; 22, 23, 38; 39]. $\mathrm{Bu}$ ilişkinin bir neticesi olarak yer şekilleri, eğim, bakı ve yükselti sınıfları toprak alt grupları içerisinde farklı boyutlarda bir dağılış gösterir. 


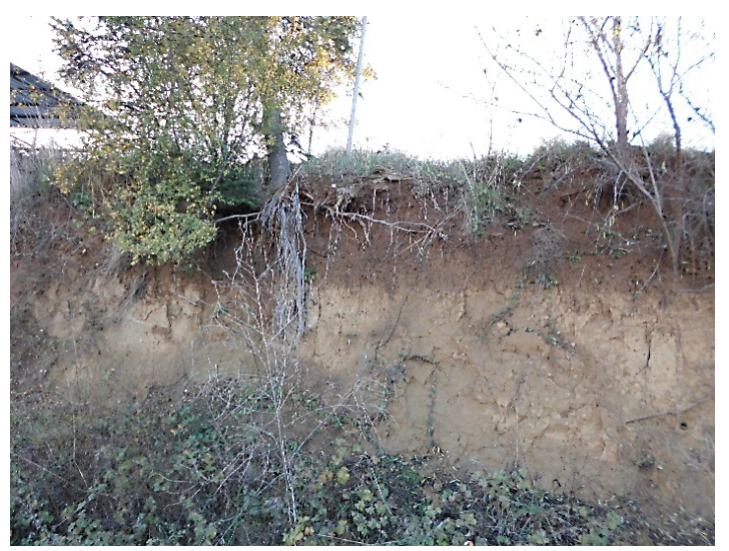

Foto 2. Havza Alanındaki İnceptisol'lerden Bir Görünüm

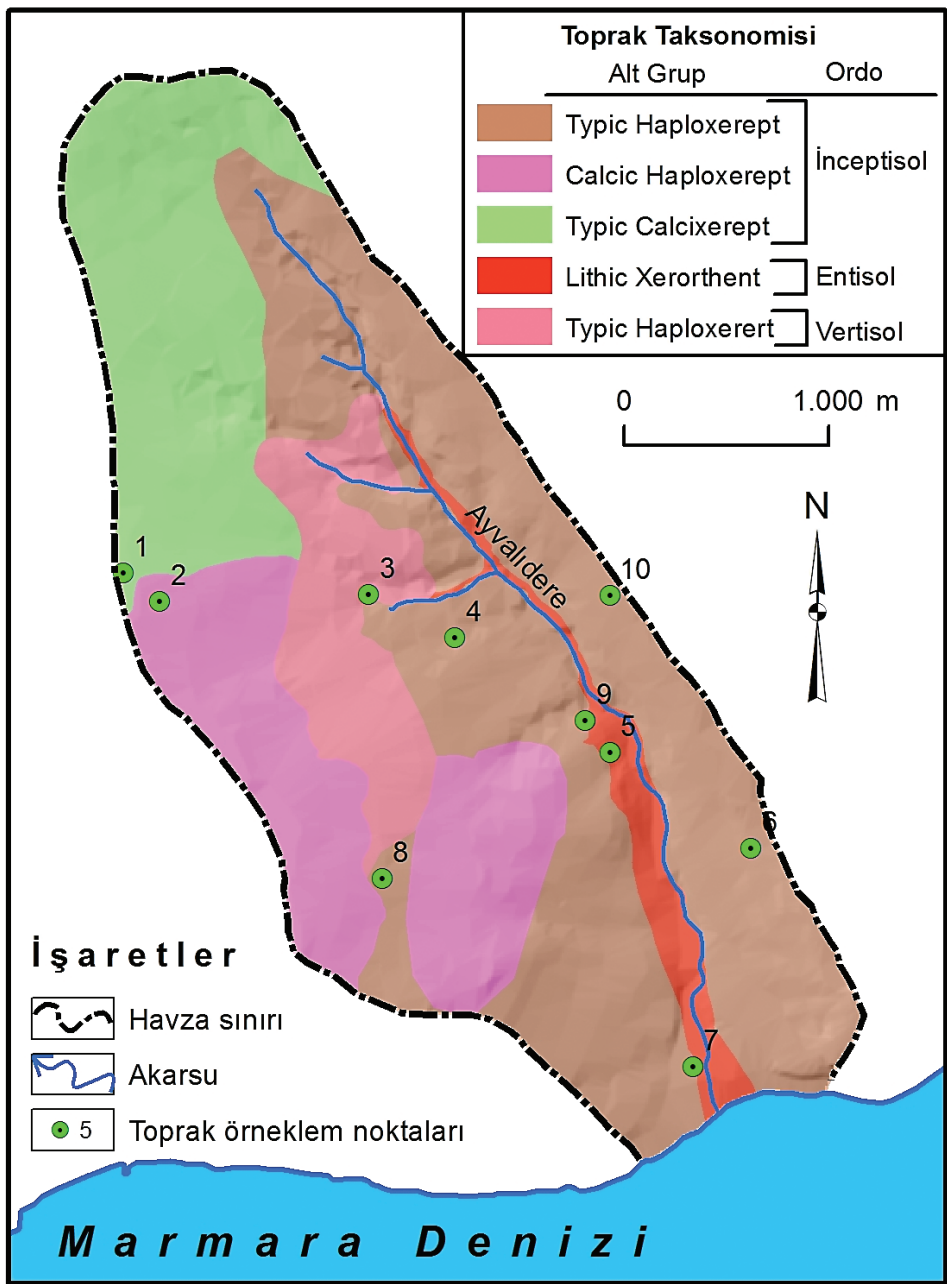

Şekil 4. Havza Alanının Toprak Haritası 
Tablo 1. Havza Alanındaki Toprakların Toprak Taksonomisine Göre Sınıflandırılması ve Yer Şekillerine Göre Dağılışları

\begin{tabular}{|c|c|c|l|l|}
\hline \multicolumn{2}{|c|}{ Toprak Taksonomisi } \\
\hline \multirow{2}{*}{ Ordo } & $\begin{array}{c}\text { Alt } \\
\text { Ordo }\end{array}$ & $\begin{array}{c}\text { Büyük } \\
\text { Grup }\end{array}$ & \multicolumn{1}{|c|}{ Alt Grup } & Yer Şekilleri \\
\hline \multirow{2}{*}{ İnceptisol } & \multirow{2}{*}{ Xerept } & $\begin{array}{c}\text { Haploxe- } \\
\text { rept }\end{array}$ & Typic Haploxerept & $\begin{array}{l}\text { Plato, Yamaç, Geniş tabanlı vadi, } \\
\text { Denizel taraça }\end{array}$ \\
\cline { 3 - 5 } & & Calcixerept & Typic Calcixerept & Plato, Yamaç \\
\cline { 3 - 6 } Entisol & \multirow{2}{*}{ Orthent } & Xerorthent & Lithic Xerorthent & Yamaç, Geniş tabanlı vadi \\
\hline \multirow{2}{*}{ Vertisol } & Xerert & $\begin{array}{c}\text { Haploxe- } \\
\text { rert }\end{array}$ & Typic Haploxerert & Plato, Yamaç, Geniş tabanlı vadi \\
\hline
\end{tabular}

Havza alanındaki toprak alt gruplarından Lithic Xerorthent'ler en fazla düz-düze yakın eğimli alüvyal vadi tabanında, doğu yönünde ve 0-50 m yükselti basamakları arasındaki sahalarda yayılış gösterir (Tablo 2; 3; Şekil 5-6-7). Typic Haploxerert’ler daha yaygın olarak hafif eğimli plato ve yamaç arazilerde, doğu yönünde ve 100-150 m yükselti basamakları arasında bulunur (Tablo 2; 3; Şekil 5-6-7). Çoğunlukla plato alanında yayılış gösteren Calcic Haploxerept'ler, Typic Haploxerert'ler ile benzer özellikteki eğim, bakı ve yükselti şartlarında izlenir (Tablo 2; 3; Şekil 5-6-7). Typic Haploxerept'ler en yoğun biçimde güneybatı yönüne bakan orta eğimli yamaç arazilerde ve 50-100 m yükselti seviyesi arasında konumlanmışlardır (Tablo 2; 3; Şekil 5-6-7). Hemen hemen sadece hafif eğimli plato alanında yayılış gösteren Typic Calcixerept'ler ise güneydoğu yönünde ve 150-200 m yükselti değerleri arasında yer almaktadır (Tablo 2; 3; Şekil 5-6-7). 
Tablo 2. Havza Alanındaki Toprak Ordolarının Yer Şekillerine ve Fiziki Özelliklerine Göre Dağılıșları (\%)

\begin{tabular}{|c|c|c|c|c|c|c|c|c|}
\hline Alt Grup & Yer Şekilleri & $\begin{array}{l}\text { Örnek } \\
\text { No }\end{array}$ & $\begin{array}{c}\text { Toprak } \\
\text { Horizonları }\end{array}$ & $\begin{array}{l}\text { Derinlik } \\
(\mathrm{cm})\end{array}$ & $\underset{(\%)}{\text { Kum }}$ & $\begin{array}{l}\text { Silt } \\
(\%)\end{array}$ & $\begin{array}{l}\text { Kil } \\
(\%)\end{array}$ & $\begin{array}{l}\text { Tekstür } \\
\text { Sinıfı }\end{array}$ \\
\hline \multirow{5}{*}{$\begin{array}{c}\text { Typic } \\
\text { Haploxerept }\end{array}$} & \multirow{5}{*}{$\begin{array}{c}\text { Plato, } \\
\text { Yamaç, } \\
\text { Geniş tabanlı } \\
\text { vadi, } \\
\text { Denizel taraça }\end{array}$} & 4 & $A, B, C$ & 104 & $\begin{array}{l}15.69- \\
31.22\end{array}$ & $\begin{array}{c}39.37- \\
55.64\end{array}$ & $\begin{array}{c}19.54- \\
40.49\end{array}$ & $\begin{array}{l}\text { Balçık, killi balçık, } \\
\text { siltli killi balçık }\end{array}$ \\
\hline & & 6 & $A, B, C$ & 75 & $\begin{array}{l}11.23- \\
24.99\end{array}$ & $\begin{array}{c}33.41- \\
61.67\end{array}$ & $\begin{array}{c}17.51- \\
51.20\end{array}$ & $\begin{array}{l}\text { Kil, siltli kil, killi } \\
\text { balçı }\end{array}$ \\
\hline & & 7 & $A, B, C$ & 55 & $\begin{array}{l}9.50- \\
57.01\end{array}$ & $\begin{array}{l}4.46- \\
62.18\end{array}$ & $\begin{array}{l}3.24- \\
63.82\end{array}$ & Kil \\
\hline & & 8 & $A, B, C$ & 160 & $\begin{array}{l}33.45- \\
42.44\end{array}$ & $\begin{array}{c}25.84- \\
34.65\end{array}$ & $\begin{array}{l}29.54- \\
34.77\end{array}$ & Killi balçık \\
\hline & & 10 & $A, B, C$ & 190 & $\begin{array}{c}38.95- \\
43.07\end{array}$ & $\begin{array}{c}29.47- \\
36.56\end{array}$ & $\begin{array}{c}22.47- \\
28.97\end{array}$ & Balçık, killi balçık \\
\hline \multirow{2}{*}{$\begin{array}{c}\text { Calcic } \\
\text { Haploxerept }\end{array}$} & \multirow{2}{*}{$\begin{array}{l}\text { Plato, } \\
\text { Yamaç }\end{array}$} & 2 & $A, B, C$ & 150 & $\begin{array}{l}5.75- \\
25.82\end{array}$ & $\begin{array}{c}29.83- \\
70.52\end{array}$ & $\begin{array}{l}21.77- \\
54.20\end{array}$ & Kil, siltli balçık \\
\hline & & 9 & $A, B, C$ & 270 & $\begin{array}{c}34.54- \\
71.26\end{array}$ & $\begin{array}{c}21.71- \\
41.30\end{array}$ & $\begin{array}{l}6.69- \\
33.85\end{array}$ & $\begin{array}{l}\text { Killi balçık, balçık, } \\
\text { siltli balçık }\end{array}$ \\
\hline $\begin{array}{c}\text { Typic } \\
\text { Calcixerept }\end{array}$ & Plato, Yamaç & 1 & $A, B, C$ & 113 & $\begin{array}{l}3.87- \\
27.60\end{array}$ & $\begin{array}{l}17.20- \\
39.94\end{array}$ & $\begin{array}{l}34.56- \\
77.48\end{array}$ & Killi balçık, kil \\
\hline $\begin{array}{c}\text { Lithic } \\
\text { Xerorthent }\end{array}$ & $\begin{array}{l}\text { Yamaç, Geniş } \\
\text { tabanlı vadi }\end{array}$ & 5 & $\mathrm{~A}, \mathrm{C}$ & 87 & $\begin{array}{l}10.00- \\
36.88\end{array}$ & $\begin{array}{l}31.02- \\
61.93\end{array}$ & $\begin{array}{c}25.85- \\
32.10\end{array}$ & $\begin{array}{l}\text { Killi balçık, siltli } \\
\text { balçık }\end{array}$ \\
\hline $\begin{array}{c}\text { Typic } \\
\text { Haploxerert }\end{array}$ & $\begin{array}{l}\text { Plato, Yamaç, } \\
\text { Geniş tabanlı } \\
\text { vadi }\end{array}$ & 3 & $\mathrm{~A}, \mathrm{C}$ & 80 & $\begin{array}{l}22.54- \\
23.39\end{array}$ & $\begin{array}{r}26.54- \\
33.68\end{array}$ & $\begin{array}{l}43.02- \\
50.07\end{array}$ & Kil \\
\hline
\end{tabular}


Tablo 3. Havza Alanının Jeomorfolojik Özelliklerinin Toprak Alt Grupları ile Karşılaştırilması (\%)

\begin{tabular}{|c|c|c|c|c|c|}
\hline $\begin{array}{c}\text { Toprak Alt } \\
\text { Grupları }\end{array}$ & $\begin{array}{c}\text { Lithic } \\
\text { Xerorthent }\end{array}$ & $\begin{array}{c}\text { Typic } \\
\text { Haploxerert }\end{array}$ & $\begin{array}{c}\text { Calcic } \\
\text { Haploxerept }\end{array}$ & $\begin{array}{c}\text { Typic } \\
\text { Haploxerept }\end{array}$ & $\begin{array}{c}\text { Typic } \\
\text { Calcixerept }\end{array}$ \\
\hline \multicolumn{7}{|c|}{ Yer Şekli Sinıfları } \\
\hline Plato & - & 70 & 84 & 8 & 97 \\
\hline Yamaç & 45 & 29 & 17 & 84 & 3 \\
\hline $\begin{array}{c}\text { Geniş tabanlı } \\
\text { vadi }\end{array}$ & 55 & 1 & - & 2 & - \\
\hline Denizel taraça & - & - & - & 6 & - \\
\hline
\end{tabular}

\begin{tabular}{|c|c|c|c|c|c|}
\hline \multicolumn{7}{|c|}{ Eğim Sinıfları (\%) } \\
\hline $\begin{array}{c}\text { Düz - düze } \\
\text { yakın }\end{array}$ & 29 & 3 & 9 & 6 & 4 \\
\hline Hafif & 11 & 59 & 60 & 19 & 52 \\
\hline Orta & 26 & 25 & 27 & 54 & 40 \\
\hline Dik & 26 & 10 & 3 & 17 & 3 \\
\hline Çok dik & 7 & 2 & - & 4 & - \\
\hline Sarp & 1 & - & - & 1 & - \\
\hline
\end{tabular}

Bakı Sınıfları (Yönler)

\begin{tabular}{|c|c|c|c|c|c|}
\hline Düz & 25 & 2 & 7 & 4 & 2 \\
\hline Kuzey & 1 & 1 & 3 & 2 & - \\
\hline Kuzeydoğu & 11 & 37 & 19 & 11 & 4 \\
\hline Doğu & 37 & 44 & 58 & 22 & 22 \\
\hline Güneydoğu & 6 & 10 & 12 & 19 & 58 \\
\hline Güney & 8 & 6 & 1 & 12 & 14 \\
\hline Güneybatı & 6 & - & - & 26 & - \\
\hline Batı & 4 & - & - & 5 & - \\
\hline Kuzeybatı & 1 & - & - & - & - \\
\hline
\end{tabular}

Yükseklik Sınıfları (m)

\begin{tabular}{|c|c|c|c|c|c|}
\hline $0-50$ & 72 & - & - & 24 & - \\
\hline $50-100$ & 26 & 6 & 12 & 44 & - \\
\hline $100-150$ & 2 & 94 & 71 & 25 & 9 \\
\hline $150-200$ & - & - & 17 & 7 & 66 \\
\hline $200-250$ & - & - & - & - & 25 \\
\hline Toplam & $\mathbf{5 1}$ & $\mathbf{1 0 3}$ & $\mathbf{1 9 1}$ & $\mathbf{4 8 0}$ & $\mathbf{2 0 4}$ \\
\hline
\end{tabular}




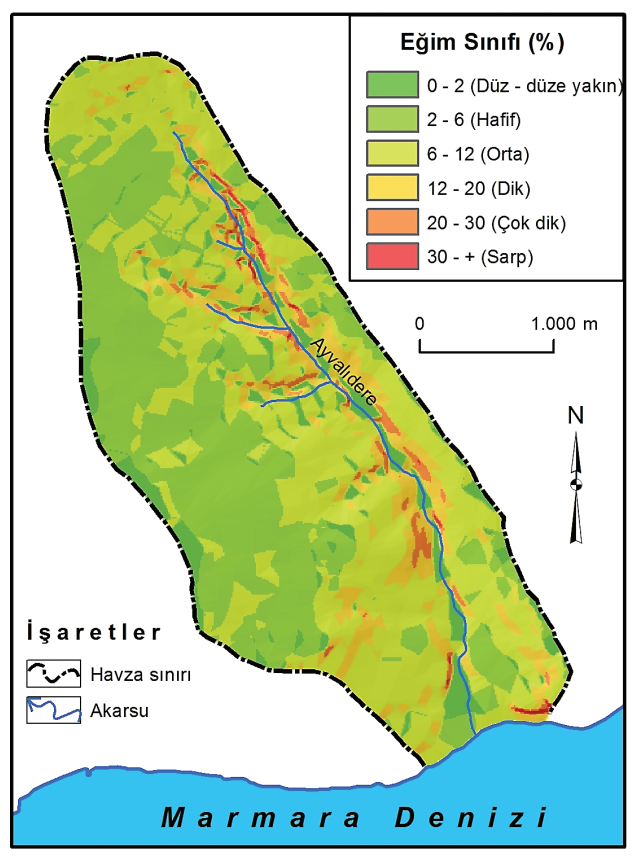

Şekil 5. Havza Alanının Eğim Haritası

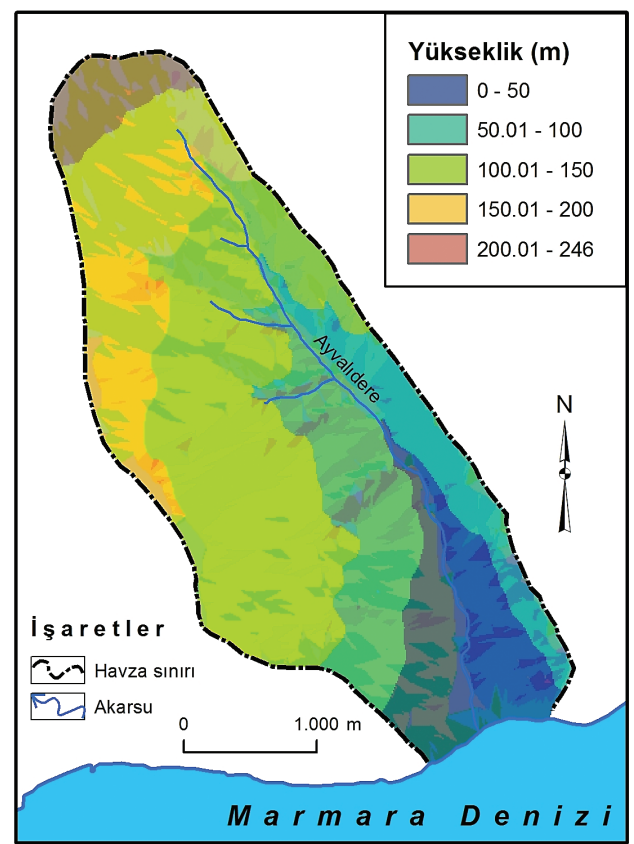

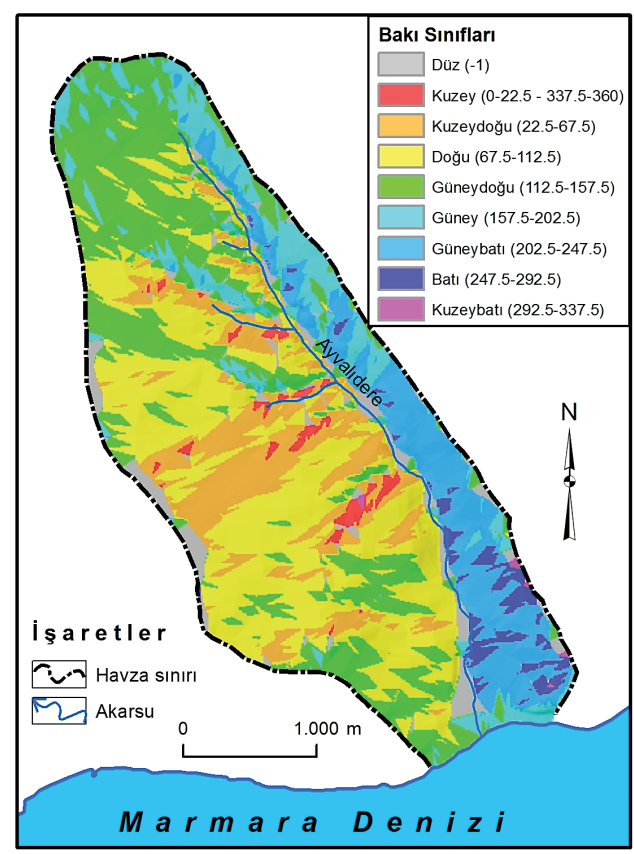

Şekil 6. Havza Alanının Bakı Haritası

Şekil 7. Havza Alanının Yükseklik Haritası 
Havza alanının jeomorfolojik özellikleri ve toprak alt grupları arasındaki münasebet, en baskın olarak yer şekillerinde kendini göstermektedir. İlgili nedenden dolayı havza alanında tanımlanan toprak ordoları yer şekilleriyle uyumlu bir dağılışa sahiptir (Tablo 1;2). Bu bağlamda bazı yer şekilleri üzerinde tek tip, bazılarında birden fazla toprak ordosu bulunur (Şekil 8). Bu değişkenlik toprak türlerinin yer şekillerine bağlı bir karakter taşıdığının işareti olarak yorumlanabilir. Zira toprak oluşumunda ve gelişiminde her şeyden önce yer şekillerinin etkili olduğu bilinmektedir [4]. Benzer durum Ayvalıdere Havzası içinde geçerlidir. Nitekim havzada plato sathı ile yamaçlarında İnceptisol veya Vertisol, denizel taraçalarda İnceptisol ve geniş tabanlı vadilerdeki alüvyal sahalarda ise Entisol ordolarına ait topraklar yayılış göstermektedir (Şekil 8; Foto 3). İlgili durum jeomorfolojik oluşum ve gelişim süreci ile toprak yapısının olgunluğu arasında paralel bir ilişkinin mevcudiyetini kanıtlamaktadır. Yani jeomorfolojik teşekkül ve tekâmül süreci ne kadar genç ise toprak oluşumu da o nispette yenidir.

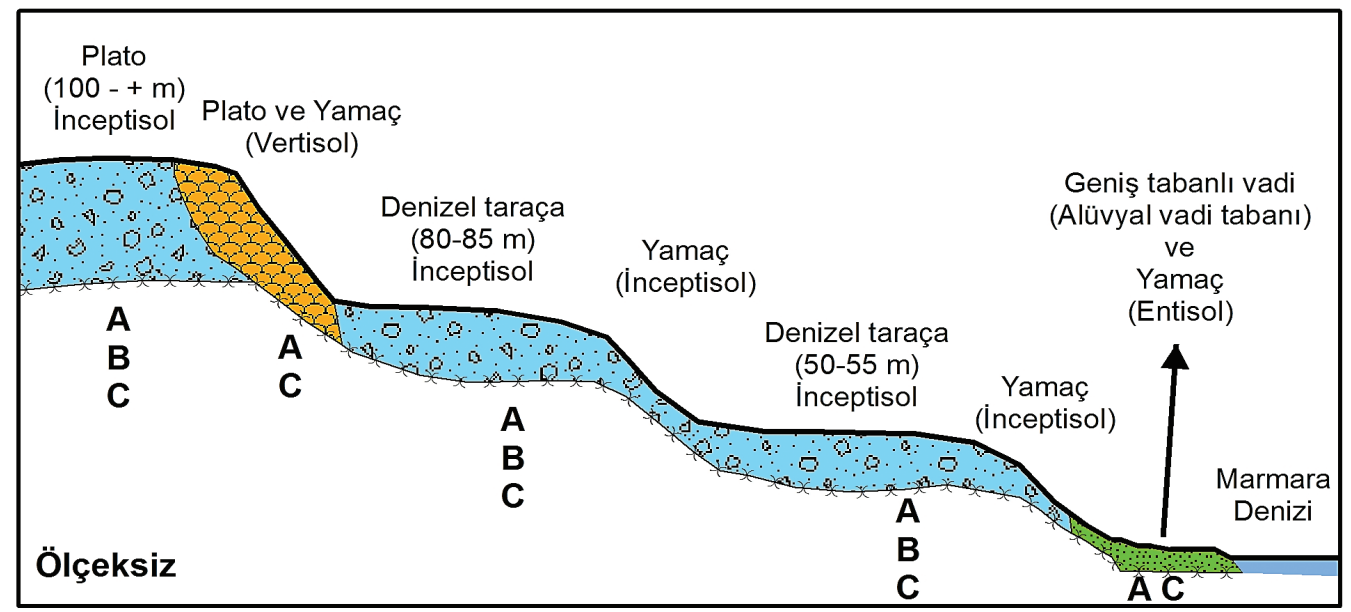

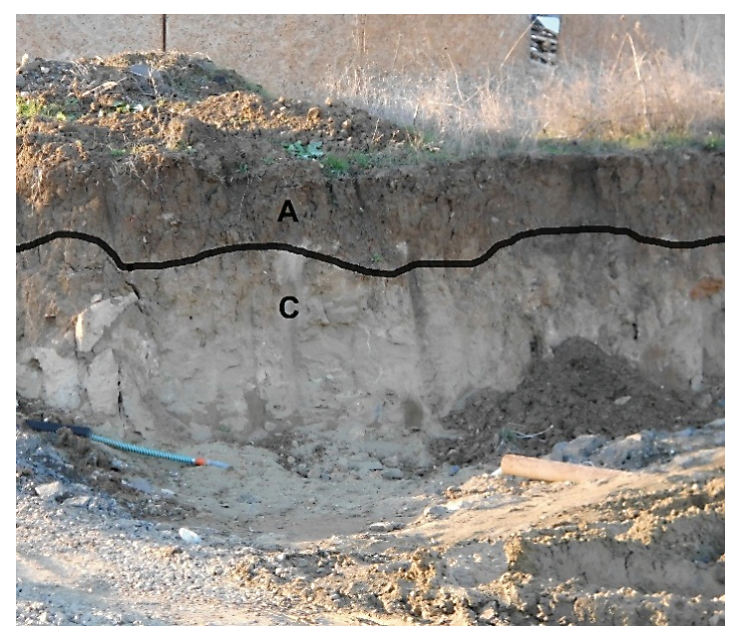

Şekil 8. Havza Alanındaki Yer Şekilleri ve Toprak Oluşumu Arasındaki İlişkiyi Anlatan Kesit

Foto 3. Havza Alanındaki Plato ve Yamaç Arazilerde Gelişen Typic Haploxerert Alt Grubundan Bir Görünüm 
Havza alanında toprak ordolarının gösterdiği bu farklılık bilhassa alt gruplarda daha belirgindir (Tablo 2). Zira İnceptisol alt grubundan olan Calcic Haploxerept ve Typic Calcixerept en fazla plato yüzeyinde bulunurken (Foto 4), denizel taraçalar ise yalnız Typic Haploxerept alt grubu tarafından örtülmektedir (Şekil 8). Keza Gönen Çayı Deltası’nda yapılan bir araştırmada Entisol ordosuna ait toprakların jeomorfolojik birimler üzerinde farklı alt gruplara ayrıldı̆̆ına dikkat çekilmiştir [8].

Havza alanında yayılış gösteren toprakların profil özellikleri de yer şekilleri tarafından etkilenmiştir. Bundan önce Özbek vd. (1981) Ceyhan Ovası’nda Ceyhan Nehri’nin kenarındaki

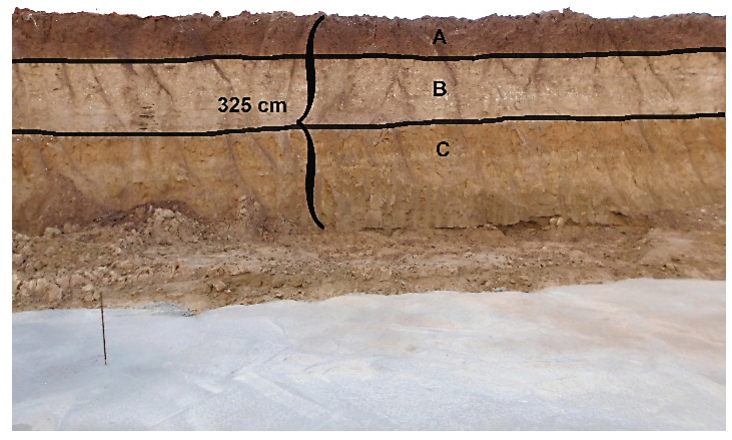

Foto 4. Havza Alanındaki Plato Üzerinde Gelişen Calcic Haploxerept Alt Grubundan Bir Görünüm

genç akarsu taraçaları üzerinde pedojenezin pek ilerlemediği sığ horizonlu toprakların mevcut olduğu, buna karşın daha yaşlı taraçalar üzerinde ise pedojenezin daha ileri düzeyde olduğu belirlemişlerdir [40]. Özşahin (2013) Gönen Çayı Deltası’nda denizden kara yönünde uzaklaştıkça pedojenezin daha da ileri bir safhaya ulaştığını ifade etmiştir [8]. Ayvalıdere Havzası’nda da önemli ölçüde yamaç arazilerde yayılış gösteren Entisol ve Vertisol ordolarında sadece A ve C horizonları teşhis edilebilirken, diğer yer şekilleri üzerinde toprak horizonlarının tümünün mevcut olduğu görülmektedir (Tablo 2). Bu durum muhtemelen yamaç arazilerde erozyonla toprak kaybının sürekli olarak devam etmesinden kaynaklanmaktadır

Yer şekilleri ile toprak arasındaki ilişki toprağın fiziksel özellikleri ve buna bağlı olarak tekstür sınıflarını da etkilemektedir. Zao vd. (2009) toprak tekstürünün ova tabanlarına yakın arazilerde orta eğimli arazilere nazaran değişik olduğunu bildirmişlerdir [41]. Duran (2013) Mersin kentinin kuzeyindeki yüksek kütleler ile yamaç arazi arasında tekstür özellikleri bakımından bariz bir ayrımın varlığına dikkat çekmiştir [42]. Bütün bu bildirilen durumlar Ayvalıdere Havzası'nda da bulunmaktadır. Nitekim havzada öncelikle ana kaya özelliklerine bağlı olsa bile bazı yer şekillerinde bazı toprak tekstür gruplarının yoğunluk kazandığı görülmektedir. Buna göre havza alanında daha çok plato alanlarında kil, yamaçlarda killi balçık, denizel taraçalarda siltli kil/killi balçık ve geniş tabanlı vadilerde ise siltli/killi balçık tekstür sınıfları yaygındır. Tekstür sınıflarında görülen bu farklılık toprakların kum, silt ve kil içeriklerinde de ayrı ayrı oranlardadir (Tablo 3). 


\section{SONUÇ VE ÖNERILER}

Yer şekilleri ve toprak arasındaki ilişkinin Ayvalıdere Havzası örneğinde açıklandı̆̆ı bu çalışmayla ulaşılan sonuçlar araştırma soruları çerçevesinde aşağıdaki şekildedir.

Havza alanında Toprak Taksonomisine göre İnceptisol, Entisol ve Vertisol ordolarına dâhil edilmiş çeşitli toprak türleri bulunur. Bu bakımdan toprak ve yer şekilleri arasında sıkı bir münasebetin var olduğu bu sahada, söz konusu ilişki kapsamında havza toprakları Toprak Taksonomisi’ne göre beş alt gruba ayrılmaktadır. Bu grupların her biri farklı yer şekilleri üzerinde izlenmektedir. Bu kapsamda genellikle plato sathı ve yamaçlar ile denizel taraçalarda İnceptisol ve Vertisol, geniş tabanlı vadinin oluşturduğu alüvyal temelde ise Entisol ordolarına ait topraklar yayılış göstermektedir. Toprakların yer şekillerine göre bu dağılış paterni, jeomorfolojik oluşum ve gelişim sürecinin gelişimi ölçüsünde toprak olgunluğunun da artacağının delili olarak yorumlanabilir. Ayrıca benzer dağılış ilişkisi toprakların fiziksel özellikleri için de geçerlidir.

Çalışmadan elde edilen bütün bu sonuçlar yer şekilleri ile toprak özellikleri arasındaki ilişkinin kısa mesafeler dâhilinde dahi büyük değişiklikler sunduğunu bir kez daha ispatlamıştır. Böylece toprak konusunda yapılacak çalışmalarda toprak ve yer şekilleri arasındaki ilişkinin daha detaylı araştırmalarla ortaya konması gereklidir. Elde edilen sonuçlarla toprağın korunması, doğru kullanımı ve planlanması konusunda önemli adımlar atılabilir. Nihai olarak gerek jeomorfolojik gerekse pedolojik özellikleri konu alan benzer çalışmalarla, toprak ve yer şekilleri arasındaki ilişkinin araștırılması doğal ortamı daha iyi anlayıp, analiz etmemize yardımcı olacaktır

\section{Yararlanılan Kaynaklar}

[1] Tricart, J. (1965). Principes et Methodes de la Geomorphologie. Paris: Masson et Cie.

[2] Kurter, A. (1982). Kastamonu ve Çevresinin Doğal Görünümü. İstanbul: İstanbul Üniversitesi Edebiyat Fakültesi Yayınları No: 2930, Edebiyat Fakültesi Matbaası.

[3] Kantarcı, D. (2000). Toprak İlmi. İstanbul: İstanbul Üniversitesi Orman Fakültesi Yayınları, İ.Ü. Yayın No: 4261, O.F. Yayın No: 462.

[4] Atalay, İ. (2011). Toprak Oluşumu, Stnıflandırması ve Coğrafyası. İzmir: Meta Basım Matbaacilık Hizmetleri.

[5] Ekinci, D. (2011). Safranbolu ve Çevresinin Jeomorfoloji Özellikleri. II. Baskı, İstanbul: Titiz Yayınevi.

[6] Dengiz, O., Gülser, C., İç, S., Kara, Z. (2009). Aşağıaksu Havzası Topraklarının Fiziksel ve Kimyasal Özellikleri ve Haritalanması. Anadolu Tarım Bilim. Dergisi, 24 (1), 34-43.

[7] Dengiz, O., Erel, A., Erkoçak, A., Durmuş, M. (2012). Kuşkonağı Havzası Temel Toprak Özellikleri, Sınıflandırılması ve Haritalanması. Ege Üniversitesi Ziraat Fakültesi Dergisi, 49 (1), 71-82. 
[8] Özşahin, E. (2013). Gönen Çayı Deltası’nın Toprak Özelliklerinin Coğrafi Açıdan Değerlendirilmesi. Ekev Akademi Dergisi, 17 (57), 233-246.

[9] Driessen, P. M., Meester, T. (1969). The soil of the Cumra area, Turkey. Agricultural Research Reports 720, Agricultural University, Wageningen, the Netherlands, Department of Tropical Soil Science, Centre for Agricultural Publishing and Documentation.

[10] Malo, D. D., Worcester, B. K., Cassel, D. K., Matzdorf, K. D. (1974). Soil Landscape Relationships in a closed drainage system. Soil Science, 38, 813-818.

[11] Ovales, F. A., Collins, M. E. (1986). Soil Landscape Relationships and Soil Variability in North Central Florida. Soil Science, 50, 401-408.

[12] Özbek, H., Güzel, N. (1975). Çukurova Üniversitesi Ziraat Fakültesi Çiftliğinde Jeomorfoloji Toprak İlişkileri. TÜBİTAK Bilim V. Kongresi, s.: 297-311.

[13] Briggs, D. J., Shishira, E. K. (1985). Soil Variability in Geomorphologically difined survey units in the Albudeite Area of Murcia Province, Spain. Catena Suppl., 6, 69-84.

[14] Dinç, U., Şenol, S., Sayın, M., Kapur, S., Güzel, N., Derici, R., Yeşilsoy, M. Ş., Yeğingil, İ., Sarı, M., Kaya, Z., Aydın, M., Kettaş, F., Berkman, A., Çolak, A. K., Yılmaz, K., Tunçgöğüs, B., Özbek, H., Gülüt, K. Y., Karaman, C., Öztürk, N., Kara, E. E. (1988). Harran Ovası Toprakları. Adana: Çukurova Üniversitesi Ziraat Fakültesi Toprak Bölümü. TÜBİTAK-TOAG 534 Nolu Proje.

[15] Agbu, P. A., Ojanuga, A. G., Olson, K. R. (1989). Soil-Landscape Relationships in the Sokoto-Rima Basin, Nigeria. Soil Science, 148 (2), 132-139.

[16] Nizeyimana, E., Bicki, T. (1992). Soil and Soil-Landscape Relationships in the North Central Region of Rwanda, East-Central Afrika. Soil Science, 153, 225-236.

[17] Mutluer, M. (1996). Orta Gediz Havzasında Yer Şekilleri ve Toprak Anamateryalinin Tarım Faaliyetleri Üzerine Etkisi. Ege Coğrafya Dergisi, 9, 267-282.

[18] Kibar, M., Dengiz, O., Bayramin, İ. (1998). Geogenesis of The Evaporative Tuzla Lake Basin Soils. Menemen-İzmir: M. Şefik Yeşilsoy International Symposium on Arid Region Soil.

[19] Akgül, M. Başyiğit, L. (2005). Süleyman Demirel Üniversitesi Çiftlik Arazisinin Detaylı Toprak Etüdü ve Haritalanması. Süleyman Demirel Üniversitesi. Fen Bilimleri Enstitüsü Dergisi, 9 (3), 1-10.

[20] Dengiz, O., Kibar, M., Yüksel, M., Kadığ̆lu, Y. K., Karaca, S., Durak, A. (2006). Farklı Yöney, Fizyografik Ünite ve Jeolojik Birimler Üzerinde Oluşmuş Toprakların Oluşumları. Tarım Bilimleri Dergisi, 12 (4), 349-356.

[21] Dengiz, O., Başkan, O. (2010). Characterization of soil profile development on different landscape in semi-arid region of Turkey a case study; Ankara-Soğulca catchment. Anadolu Tarım Bilimleri Dergisi, 25 (2), 106-112. 
[22] Özşahin, E., Atasoy, A. (2015). Aşağı Asi Nehri Havzası Topraklar. Gaziantep University Journal of Social Sciences, 14 (1), 127-153.

[23] Özşahin E. (2015). Şehir ve Toprak Arasındaki İlişkinin Coğrafi Yaklaşımla İncelenmesi: Tekirdağ Şehri Örneği. Turkish Studies International Periodical For The Languages, Literature and History of Turkish or Turkic, 10/3, 733-758.

[24] Kayran, H. (2006). Tekirdağ Belediyesi Kent ve Mücavir Alanının Revizyon İmar Planı Yerleşime Uygunluk Amaçlı Etüt Raporu, Çağıl Mühendislik Müşavirlik Sanayi ve Ticaret Ltd. Şti., Tekirdağ: Tekirdağ Belediyesi.

[25] Özşahin E. (2014). Coğrafi Bilgi Sistemleri (CBS) ve Analitik Hiyerarşi Süreci (AHS) kullanılarak Tekirdağ ilinde deprem hasar riski analizi. Uluslararası İnsan Bilimleri Dergisi, $11(1), 861-879$.

[26] Özşahin E. (2014). CBS Kullanılarak Şehir ve Jeomorfoloji Arasındaki İlişkinin İncelenmesi: Tekirdağ Şehri Örneği. Iğdır Üniversitesi Sosyal Bilimler Dergisi, 6, 93-122.

[27] Meteoroloji Genel Müdürlüğü (2015). Tekirdağ Meteoroloji İstasyonuna ait uzun yıllar içinde gerçekleşen ortalama değerler (1954 - 2013). Ankara: Meteoroloji Genel Müdürlüğü.

[28] Koçman, A. (1993). Türkiye İklimi. İzmir: Ege Üniversitesi Edebiyat Fakültesi Coğrafya Bölümü.

[29] Günay, A. (2007). Tekirdăg’̀n İklim Özellikleri. Yayınlanmamış Yüksek Lisans Tezi, İstanbul: İstanbul Üniversitesi Sosyal Bilimler Enstitüsü Coğrafya Anabilim Dalı.

[30] Ekinci, H. (1990). Türkiye Genel Toprak Haritasının Toprak Taksonomisine Göre Düzenlenebilme Olanaklarının Tekirdağ Bölgesi Örneğinde Araştırılması. Yayınlanmamış Doktora Tezi, Adana: Çukurova Üniversitesi Fen Bilimleri Enstitüsü Toprak Anabilim Dalı.

[31] Boyraz, D. (2003). Kayı ve Aydınpinar Dereleri (Tekirdağ) Arasında Yer Alan Oligosen Marin ve Kuaterner Alüviyal Çökellerin Üzerinde Oluşmuş Toprakların Genesisleri, Katenasal ve Toposequens İlişkileri. Yayınlanmamış Doktora Tezi, Tekirdağ: Trakya Üniversitesi Fen Bilimleri Enstitüsü Toprak Anabilim Dalı.

[32] Sarı, H. (2010). Tekirdağ Merkez Bağlar Sirtları Mevkii de Yer Alan Toprakların Katenasal İlişkilerinin Belirlenmesi. Yayınlanmamış Yüksek Lisans Tezi, Tekirdağ: Namık Kemal Üniversitesi Fen Bilimleri Enstitüsü Toprak Anabilim Dalı.

[33] Boyraz, D., Sarı, H. (2012). Tekirdağ Değirmenaltı-Muratlı Kavşağ ran Katenadaki Toprakların Fiziksel ve Zemin Özelliklerinin Değerlendirilmesi. Tekirdăg Ziraat Fakültesi Dergisi, 9 (3), 68-78.

[34] Atmaca, B. (2011). Tekirdă̆ Merkez İlçesi Sahil Şeridini Oluşturan Doğal Drenaj Sisteminde Yer Alan Toprakların Mühendislik Özelliklerinin Değerlendirilmesi. Yayınlanmamış Doktora Tezi, Tekirdağ: Namık Kemal Üniversitesi Fen Bilimleri Enstitüsü Toprak Anabilim Dalı. 
[35] Aydın, M., Kılıç, Ş. (2010). Toprak Bilimi. Ankara: Nobel Yayın Dağıtım.

[36] Tunçay, T., Bayramin, İ. (2010). Çiçekdağ-Kırşehir tarım işletmesi topraklarının detaylı toprak etüt ve haritalanması. Anadolu Tarım Bilimleri Dergisi, 25 (1), 53-60.

[37] Tonbul, S. (1989). Elazığ Batısının Toprak Coğrafyası. Fırat Üniversitesi Sosyal Bilimler Dergisi, 3 (1), 211-233.

[38] Efe, R. (1999). Güney Marmara Bölümü Batısında Toprak Oluşumunu Etkileyen Coğrafi Faktörler ve Toprakların Özellikleri. Türk Coğrafya Dergisi, 34, 193-209.

[39] Zeybek, H. İ. (2003). Turhal Ovası ve Yakın Çevresi Toprakları. Türk Coğrafya Dergisi, 41, 41-60.

[40] Özbek, H., Şenol, S., Dinç, U., Kapur, S., Güzel, N. (1981). Ceyhan Ovası Topraklarının Genesisi, Önemli Fiziksel, Kimyasal Özellikleri ve Sinıflandırılması Üzerinde Araştırmalar. Adana: TÜBİTAK, TOAG, SUBTUNITT 6.

[41] Zhao, Z., Chow, T. L., Rees, H. W., Yang, Q., Xing, Z., Meng, F. R. (2009). Predict Soil Texture Distributions Using an Artificial Neural Network Model. Computers and Electronics in Agriculture, 65, 36-48.

[42] Duran, C. (2013). Üç Farklı Anakayadan Oluşmuş Orman Topraklarının Tekstür Özellikleri ve Haritalanması (Mersin Kentinin Kuzeyi). 3rd International Geography Symposium - GEOMED 2013, Editors: Recep Efe, Ibrahim Atalay, Isa Cürebal, s.: 371-380.

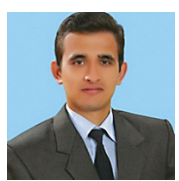

Emre ÖZŞAHİN - eozsahin@nku.edu.tr, ozsahine@hotmail.com

Dr. Emre Ozsahin was born in Gönen, Balikesir. He completed his primary, secondary and high schools in Gönen. He finished his undergraduate education in Faculty of Sciences and Literature, Balikesir University and his MA and PhD in Institute of Social Sciences, Istanbul University. Ozsahin worked as an expert from 2008 to 2013 at the Department od Geography, Faculty of Sciences and Literature, Mustafa Kemal University, Hatay. In 2013, he was appointed as an assistant professor to the Department od Geography, Faculty of Sciences and Literature, Namık Kemal University. Dr. Ozsahin has published many papers for both national and international fields, and participated in conferences and symposia. He continues to work on Geography, Geomorphology, Soil, Hydrography, Geographical Information Systems (GIS), Remote Sensing (RS), Geographic Modelling. He is married and speaks English. 
